\title{
ORIGINAL
}

\section{Synthesis and Properties of $\alpha, \omega$-Bisamidobetaine-type Amphoteric Surfactants from Long-chain Dibasic Acids}

\author{
Shingo Yamamura, Shin-ichi OGawa, Keisuke Honda, \\ Masaki NAKAMURA, and Tokuji TAKEDA \\ Osaka Municipal Technical Research Institute \\ (1-6-50, Morinomiya, Joto-ku, Osaka $\bar{\top} 536$ )
}

\begin{abstract}
$\alpha, \omega$-Type amphoteric surfactants containing bisbetaine groups were synthesized by reactions of alkanedioic acids with $N, N$-dimethyl-1,3-propanediamine, followed by quaternization of the resulting bisaminoamides with sodium chloroacetate. The latter process was carried out in water or a mixture of isopropy! alcohol and water using sodium hydrogencarbonate or sodium hydroxide as the catalyst.

The properties of the $\alpha, \omega$-bisamidobetaine in aqueous solution were studied. $\alpha, \omega$-Bisamidos betaines derived from hexadecanedioic and icosanedioic acid showed good catalytic activity for the halide displacement reaction and a excellent ability to bring about lime soap dispersion.
\end{abstract}

\section{Introduction}

Interest in amphoteric surfactants of betainetype has increased since they combine a positive as well as a negative charge in one molecule and have unique properties such as compati= bility with any type of surfactants, high stac bility in hard water and very low eye and skin irritation ${ }^{1)}$.

$\alpha, \omega$-Type surfactants possessing two func $=$ tional groups in both sides of the molecule have been known to show the large molecular area because of bulkiness of molecule and disturbance of dense adsorption ${ }^{2)}$. Most of the works deal with anionic and nonionic surfactants; $\alpha, \omega$-alkanedicarboxylates ${ }^{3), 4)}, \alpha$, $\omega$-bis(3-sulfopropoxycarbonyl) alkanes ${ }^{5)}, \alpha, \omega$ alkane disulfates ${ }^{6)}, \alpha, \omega$-bis ( $p$-sulfophenoxy) alkanes $^{7)}$, and $\alpha, \omega$-alkane bis[poly(oxyethy $=$ lene)] ethers ${ }^{8)}$.

Recently, the synthesis of $\alpha, \omega$-type ampho= teric surfactants from $\alpha, \omega$-dihalododecane have been reported ${ }^{2)}$.

More recently, we also have reported a new type of bis[2-(trimethylammonio).ethyl] $\alpha, \omega$ alkanedioate diiodides ${ }^{9)}$ and $\alpha, \omega$-bisamido $=$ betaines ${ }^{10)}$.

This paper describes the synthesis of $\alpha, \omega$ bisamidobetaines from $\alpha, \omega$-dicarboxylic acids, which have become commercially available, and the properties of resulting $\alpha, \omega$-bisamidos betaines. We have expected that the introduc= tion of the bulky $\alpha, \omega$-difunctional groups and amido groups into the molecule would result in an enhancement of the lime soap dispersing ability.

\section{Experimental}

\subsection{Materials}

Dodecanedioic acid was the commercial reagent (Tokyo Kasei Co., extra pure grade). Hexadecanedioic and icosanedioic acids were obtained from Okamura Oil Mill Ltd., Their purities determined by gas chromatography of their methyl esters exceeded 98\%. $N, N$ Dimethyl-1,3-propanediamine and sodium chloroacetate were obtained from Tokyo Kasei Kogyo Co. and Wako Pure Chemical Co., respectively. 3-(Decanoylamino) propyldimeth= ylammonioacetate (C 10 monoamidobetaine) was synthesized from the reaction of decanoic acid and $N, N$-dimethyl-1,3-propanediamine, followed by quaternization of the resulting aminoamide. Commercial $\mathrm{N}$-dodecylbetaine (AM-301, commercial C 12 monobetaine) and 3-(dodecanoylamino) propyldimethylammonios acetate(AM 3130, commercial C 12 monoamido= betaine) were supplied by NIKKO Chemical 
Co. Ltd. and were used after drying in vacuo.

Tetraethylammonium bromide (TEAB) and tetrabutylammonium bromide (TBAB) were commercial reagents (Tokyo Kasei Kogyo Co.) and were used without further purification.

2.2 Synthesis of $N, N^{\prime}$-Bis [3-(dimeth= ylamino) propyl] dodecanediamide (C 12 Bisaminoamide)

A mixture of $N, N$-dimethyl-1,3-propane= diamine $(0.72 \mathrm{~mol}, 73.6 \mathrm{~g})$, dodecanedioic acid $(0.30 \mathrm{~mol}, 69.0 \mathrm{~g})$ and xylene $(70 \mathrm{~mL})$ was charged into a four necked $300 \mathrm{~mL}$ flask equipped with stirrer, a thermometer and a Dean-Stark water separator. The solution was heated while stirring at the reflux temperature $\left(140 \sim 146^{\circ} \mathrm{C}\right)$. Theoretical amounts $(10.8 \mathrm{~g})$ of water were removed azeotropically for about $5 \mathrm{~h}$. The product was crystallized twice from benzene to yield $109.0 \mathrm{~g}(96 \%)$ of

crystalline solid. The following melting point and analytical data were observed for this derivative.

$\mathrm{mp}: 112.3 \sim 112.8^{\circ} \mathrm{C}$

Analysis: C $66.18 \%, \mathrm{H} 11.66 \%, \mathrm{~N} 13.90 \%$

Calcd. for $\mathrm{C}_{22} \mathrm{H}_{46} \mathrm{~N}_{4} \mathrm{O}_{2}$ : C $66.29 \%, \mathrm{H} 11.63 \%$, $\mathrm{N} 14.05 \%$ IR(KBr): $3320,2920,2850,2760$, $1645,1550,1485,1420,1385,1340,1240,1190$, $1040,840,720 \mathrm{~cm}^{-1}$.

$\mathrm{NMR}$ (in $\left.\mathrm{CDCl}_{3}, \delta \mathrm{ppm}\right): 1.28\left(12 \mathrm{H}, \mathrm{s}, \mathrm{CH}_{2}\right)$, $1.5 \sim 1.9\left(8 \mathrm{H}, \mathrm{m}, \mathrm{N}-\mathrm{C}-\mathrm{CH}_{2}\right.$ and $\left.\mathrm{CO}-\mathrm{C}-\mathrm{CH}_{2}\right)$, 2. $05 \sim 2.2\left(4 \mathrm{H}, \mathrm{m}, \mathrm{CH}_{2} \mathrm{CO}\right), 2.23(12 \mathrm{H}, \mathrm{s}, \mathrm{N}-$ $\left.\mathrm{CH}_{3}\right), 2.38\left(4 \mathrm{H}, \mathrm{t}, J=7.0 \mathrm{~Hz}, \mathrm{~N}-\mathrm{CH}_{2}\right), 3.2 \sim$ $3.5\left(4 \mathrm{H}, \mathrm{m}, \mathrm{CO}-\mathrm{N}-\mathrm{CH}_{2}\right), 6.8 \sim 7.0(2 \mathrm{H}, \mathrm{m}$, $\mathrm{NH})$.

2.3 Synthesis of $N, N^{\prime}$-Bis [3-(dimeth= ylamino)propyl]hexadecanediamide (C 16 Bisaminoamide)

A mixture of $N, N$-dimethyl-1,3-propane= diamine $(0.40 \mathrm{~mol}, 40.9 \mathrm{~g})$, hexadecanedioic acid $(0.16 \mathrm{~mol}, 47.7 \mathrm{~g})$ and xylene $(100 \mathrm{~mL})$ was refluxed $\left(138^{\circ} \mathrm{C}\right)$ for $7.5 \mathrm{~h}$. The product was crystallized from acetone to yield $63.3 \mathrm{~g}$ (87\%) of $\mathrm{C} 16$ bisaminoamide. The following melting point and analytical data were observed for this derivative.

$\mathrm{mp}: 117 \sim 117.5^{\circ} \mathrm{C}$

Analysis: C $69.04 \%, \mathrm{H} 11.83 \%$, N $11.97 \%$

Calcd. for $\mathrm{C}_{26} \mathrm{H}_{54} \mathrm{~N}_{4} \mathrm{O}_{2}: \mathrm{C} 68.67 \%, \mathrm{H} 11.97 \%$, $\mathrm{N} 12.32 \%$

$\mathrm{IR}(\mathrm{KBr}): 3300,2900,2840,2800,2750,1638$,
$1530,1470,1418,1380,1295,1250,710 \mathrm{~cm}^{-1}$. $\mathrm{NMR}$ (in $\left.\mathrm{CDCl}_{3}, \delta \mathrm{ppm}\right): 1.22\left(20 \mathrm{H}, \mathrm{s}, \mathrm{CH}_{2}\right)$, 1. $45 \sim 1.80\left(8 \mathrm{H}, \mathrm{m}, \mathrm{CH}_{2}-\mathrm{C}-\mathrm{CO}\right.$ and $\left.\mathrm{N}-\mathrm{C}-\mathrm{CH}_{2}\right)$, 2. $05 \sim 2.16\left(4 \mathrm{H}, \mathrm{m}, \mathrm{CH}_{2} \mathrm{CO}\right), 2.23(12 \mathrm{H}, \mathrm{s}$, $\left.\mathrm{N}-\mathrm{CH}_{3}\right), 2.38\left(4 \mathrm{H}, \mathrm{t}, J=6.7 \mathrm{~Hz}, \mathrm{~N}-\mathrm{CH}_{2}\right), 3.2$ $\sim 3.4\left(4 \mathrm{H}, \mathrm{m}, \mathrm{CO}-\mathrm{N}-\mathrm{CH}_{2}\right), 6.8 \sim 6.9(2 \mathrm{H}, \mathrm{m}$, $\mathrm{NH})$.

2.4 Synthesis of $N, N^{\prime}$-Bis [3-(dimeth= ylamino) propyl] icosanediamide (C 20 Bisaminoamide)

A mixture of $\mathrm{N}, \mathrm{N}$-dimethyl-1,3-propane= diamine $(0.36 \mathrm{~mol}, 36.7 \mathrm{~g})$, icosanedioic acid $(0.15 \mathrm{~mol}, 51.4 \mathrm{~g})$ and xylene $(50 \mathrm{~mL})$ was refluxed $\left(135 \sim 150^{\circ} \mathrm{C}\right)$ for $16 \mathrm{~h}$. The product was crystallized from acetone to yield $71.2 \mathrm{~g}$ (93\%) of C 20 bisaminoamide. The following melting point and analytical data were obser= ved for this derivative.

$\mathrm{mp}: 120 \sim 120.5^{\circ} \mathrm{C}$.

Analysis: C 70.34\%, H 12.40\%, N 10.40\%.

Calcd. for $\mathrm{C}_{30} \mathrm{H}_{62} \mathrm{~N}_{4} \mathrm{O}_{2}$ : C 70.54\%, $\mathrm{H} 12.23 \%$, N 10.97\%.

IR(KBr): $3280,2880,2830,2740,1630,1520$, $1450,1410,1375,1255,1230,1200,1175,1035$ $\mathrm{cm}^{-1}$.

$\mathrm{NMR}$ (in $\left.\mathrm{CDCl}_{3}, \delta \mathrm{ppm}\right): 1.24\left(28 \mathrm{H}, \mathrm{s}, \mathrm{CH}_{2}\right)$, $1.5 \sim 1.8\left(8 \mathrm{H}, \mathrm{m}, \mathrm{CH}_{2}-\mathrm{C}-\mathrm{CO}\right.$ and $\left.\mathrm{N}-\mathrm{C}-\mathrm{CH}_{2}\right)$, $2.07 \sim 2.2\left(4 \mathrm{H}, \mathrm{m}, \mathrm{CO}-\mathrm{N}-\mathrm{CH}_{2}\right), 6.8 \sim 7.0(2$ $\mathrm{H}, \mathrm{m}, \mathrm{NH})$.

\subsection{Quaternization of Bisaminoamide}

To a $100 \mathrm{~mL}$ flask equipped with a bar magnet and a condenser were added $\mathrm{C} 12$ bisaminoamide $(20 \mathrm{mmol}, 7.9 \mathrm{~g})$, sodium chlo= roacetate $(50 \mathrm{mmol}, 5.8 \mathrm{~g})$, sodium hydrogen= carbonate $(4 \mathrm{mmol}, 0.3 \mathrm{~g})$ or sodium hydroxide $(4 \mathrm{mmol}, 0.2 \mathrm{~g}$ ) and $9 \mathrm{~mL}$ of water or the mixture of isopropyl alcohol and water. The mixture was refluxed $\left(83 \sim 86^{\circ} \mathrm{C}\right)$ for $6 \mathrm{~h}$, after which the solvent was stripped off. The filtrate was concentrated and purified on silica-gel (Wakogel C 200) column $(30 \times 500 \mathrm{~mm})$ using the mixed solvents of methyl alcohol/ethyl alcohol/isopropyl alchol/28\% ammonia (3/3/3/ $0.6 \sim 3)$. The resulting white crystalline pro= duct was analyzed by the usual technique and had no ash. The reaction mixtures of other bisaminoamides were treated in the same procedure and the products were isolated.

\subsection{Surface Tension Measurements}

The purified $\alpha, \omega$-bisamidobetaines were 
dissolved in quartz-distilled wtaer. All surface tension measurements were made by Du Nouy tensiometer.

\subsection{Catalytic Activity for the Halide} Displacement Reaction

A $10 \mathrm{~mL}$ flask was charged with $\alpha, \omega$-bis $=$ amidobetaine $(0.25 \mathrm{mmol}, 5 \mathrm{~mol} \%$ based on 1 bromooctane), 1-bromooctane (5 mmol, $1 \mathrm{~g})$, sodium iodide $(6.7 \mathrm{mmol}, 1 \mathrm{~g})$ and $5 \mathrm{~mL}$ of water. This mixture was stirred by mean of a magnetic stirrer, and the flask immersed in an oil bath maintained at $100^{\circ} \mathrm{C}$ for $7 \mathrm{~h}$. The product was determined by gas liquid chroma= tography (silicone OV-1 $1.5 \%$ on Shimalite W, $2 \mathrm{~m} \times 3 \mathrm{~mm}$ ) using an internal standard of 6 undecanone.

\subsection{Lime Soap Dispersing Ability}

Lime soap dispersant requirement (LSDR) was obtained by the Borghetty-Bergman pros cedure $^{11)}$. The values represent the grams of compound required to prevent precipitation of $100 \mathrm{~g}$ of sodium oleate in hard water of 333 ppm $(\mathrm{Ca} / \mathrm{Mg}=3 / 2)$.

\section{Results and Discussion}

\subsection{Synthesis of $\alpha$ - $\omega$-Bisamidobetaines}

The reaction of bisaminoamide $(\mathbf{a} \sim \mathbf{c})$ with sodium chloroacetate in the presence of sodium hydrogencarbonate in refluxing a mixture of isopropyl alcohol and water gave $\alpha, \omega$-alkane= dioylbis [(3-aminopropyl) dimethylammonioace $=$ tate] $(2 \mathbf{a} \sim \mathbf{c})$ in the yield of $64 \sim 79 \%$.

Thin-layer chromatography using the mixed developing solvent $(3 / 3 / 3 / 2 \mathrm{vol} / \mathrm{vol})$ of methanol,

Table-1 Analytical data of the products.

\begin{tabular}{|c|c|c|c|c|c|}
\hline \multirow{2}{*}{ Product } & \multicolumn{3}{|c|}{$\begin{array}{c}\text { Elemental analysis (\%) } \\
\text { Obs. (Calcd.) }\end{array}$} & \multirow{2}{*}{$\begin{array}{c}\left.\text { NMR (in } \mathrm{D}_{2} \mathrm{O}\right) \\
\delta(\mathrm{ppm})\end{array}$} & \multirow{2}{*}{$\begin{array}{c}\mathrm{IR} \\
\left(\mathrm{cm}^{-1}\right)\end{array}$} \\
\hline & C & $\mathrm{H}$ & $\mathrm{N}$ & & \\
\hline $2 a^{* 1}$ & $\begin{array}{c}54.99 \\
(54.91)\end{array}$ & $\begin{array}{c}9.85 \\
(9.92)\end{array}$ & $\begin{array}{c}9.67 \\
(9.85)\end{array}$ & $\begin{array}{l}1.3 \sim 1.5\left(16 \mathrm{H}, \mathrm{m}, \mathrm{CH}_{2}\right), 2.1 \sim 2.4\left(8 \mathrm{H}, \mathrm{m}, \mathrm{COCH}_{2} \text { and } \mathrm{N}-\mathrm{C}-\right. \\
\left.\mathrm{CH}_{2}\right), 3.23\left(12 \mathrm{H}, \mathrm{s}, \mathrm{N}^{+}-\mathrm{CH}_{3}\right), 3.3 \sim 3.8\left(8 \mathrm{H}, \mathrm{m}, \mathrm{N}^{+}-\mathrm{CH}_{2} \text { and }\right. \\
\left.\mathrm{N}-\mathrm{CH}_{2}\right), 3.87\left(4 \mathrm{H}, \mathrm{s}, \mathrm{N}^{+}-\mathrm{CH}_{2}-\mathrm{COO}^{-}\right)\end{array}$ & $\begin{array}{l}3280 \\
1635 \\
1550\end{array}$ \\
\hline $2 \mathbf{b} * 2$ & $\begin{array}{c}61.14 \\
(61.19)\end{array}$ & $\begin{array}{c}10.02 \\
(10.27)\end{array}$ & $\begin{array}{c}9.39 \\
(9.52)\end{array}$ & $\begin{array}{l}1.28\left(20 \mathrm{H}, \mathrm{s}, \mathrm{CH}_{2}\right), 1.5 \sim 1.7\left(4 \mathrm{H}, \mathrm{m}, \mathrm{CO}-\mathrm{C}_{-} \mathrm{CH}_{2}\right), 1.9 \sim 2.3 \\
\left(8 \mathrm{H}, \mathrm{m}, \mathrm{COCH}_{2} \text { and } \mathrm{N}-\mathrm{C}^{-} \mathrm{CH}_{2}\right), 3.22\left(12 \mathrm{H}, \mathrm{s}, \mathrm{N}^{+}-\mathrm{CH}_{3}\right), 3.3 \sim \\
3.7\left(8 \mathrm{H}, \mathrm{m}, \mathrm{N}^{+}-\mathrm{CH}_{2} \text { and } \mathrm{N}-\mathrm{CH}_{2}\right), 3.83\left(4 \mathrm{H}, \mathrm{N}^{+}-\mathrm{CH}_{2}-\mathrm{COO}^{-}\right)\end{array}$ & $\begin{array}{l}3300 \\
1630 \\
1600 \\
1535\end{array}$ \\
\hline $2 c^{* 2}$ & $\begin{array}{c}63.29 \\
(63.32)\end{array}$ & $\begin{array}{c}10.73 \\
(10.63)\end{array}$ & $\begin{array}{r}8.57 \\
(8.69)\end{array}$ & 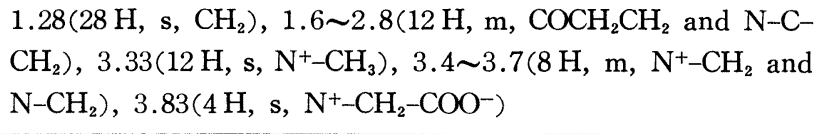 & $\begin{array}{l}3300 \\
1630 \\
1535\end{array}$ \\
\hline $3 a^{* 1}$ & $\begin{array}{c}56.37 \\
(56.44)\end{array}$ & $\begin{array}{c}10.73 \\
(10.66)\end{array}$ & $\begin{array}{c}10.51 \\
(10.97)\end{array}$ & $\begin{array}{l}1.2 \sim 1.5\left(16 \mathrm{H}, \mathrm{m}, \mathrm{CH}_{2}\right), 1.5 \sim 2.3\left(10 \mathrm{H}, \mathrm{m}, \mathrm{COCH}_{2}, \mathrm{CON}-\mathrm{C}-\right. \\
\left.\mathrm{CH}_{2} \text { and } \mathrm{N}-\mathrm{CH}_{2}\right), 2.5\left(6 \mathrm{H}, \mathrm{s}, \mathrm{N}-\mathrm{CH}_{3}\right), 3.23\left(6 \mathrm{H}, \mathrm{s}, \mathrm{N}^{+}-\mathrm{CH}_{3}\right) \text {, } \\
3.1 \sim 3.6\left(6 \mathrm{H}, \mathrm{m}, \mathrm{N}^{+}-\mathrm{CH}_{2} \text { and } \mathrm{CON}_{-}-\mathrm{CH}_{2}\right), 3.78\left(2 \mathrm{H}, \mathrm{s}, \mathrm{N}^{--}\right. \\
\left.\mathrm{CH}_{2}-\mathrm{COO}^{-}\right)\end{array}$ & $\begin{array}{l}3250 \\
1640 \\
1550\end{array}$ \\
\hline $3 \mathbf{b} * 2$ & $\begin{array}{c}63.42 \\
(63.36)\end{array}$ & $\begin{array}{c}10.76 \\
(11.02)\end{array}$ & $\begin{array}{c}10.45 \\
(10.56)\end{array}$ & $\begin{array}{l}1.26\left(20 \mathrm{H}, \mathrm{s}, \mathrm{CH}_{2}\right), 1.5 \sim 2.04\left(8 \mathrm{H}, \mathrm{m}, \mathrm{CO}-\mathrm{C}-\mathrm{CH}_{2} \text { and } \mathrm{CON}-\right. \\
\left.\mathrm{C}^{-} \mathrm{CH}_{2}\right), 2.19\left(4 \mathrm{H}, \mathrm{t}, J=6.7 \mathrm{~Hz}, \mathrm{COCH}_{2}\right), 2.54(6 \mathrm{H}, \mathrm{s}, \mathrm{N}- \\
\left.\mathrm{CH}_{3}\right), 2.74\left(2 \mathrm{H}, \mathrm{t}, J=5.1 \mathrm{~Hz}, \mathrm{~N}-\mathrm{CH}_{2}\right), 3.18\left(6 \mathrm{H}, \mathrm{s}, \mathrm{N}^{+}-\mathrm{CH}_{3}\right) \text {, } \\
3.1 \sim 3.6\left(6 \mathrm{H}, \mathrm{m}, \mathrm{N}^{+}-\mathrm{CH}_{2} \text { and } \mathrm{CON}_{-} \mathrm{CH}_{2}\right), 3.78\left(2 \mathrm{H}, \mathrm{s}, \mathrm{N}^{+-}\right. \\
\left.\mathrm{CH}_{2}-\mathrm{COO}^{-}\right)\end{array}$ & $\begin{array}{l}3300 \\
1630 \\
1540\end{array}$ \\
\hline $3 c^{* 2}$ & $\begin{array}{c}65.71 \\
(65.49)\end{array}$ & $\begin{array}{c}11.31 \\
(11.34)\end{array}$ & $\begin{array}{c}9.60 \\
(9.55)\end{array}$ & $\begin{array}{l}1.26\left(32 \mathrm{H}, \mathrm{s}, \mathrm{CH}_{2}\right), 1.6 \sim 2.5\left(10 \mathrm{H}, \mathrm{m}, \mathrm{COCH}_{2} \text { and } \mathrm{CON}-\mathrm{C}-\right. \\
\left.\mathrm{CH}_{2}, \mathrm{~N}-\mathrm{CH}_{2}\right), 2.56\left(6 \mathrm{H}, \mathrm{s}, \mathrm{N}-\mathrm{CH}_{3}\right), 3.1 \sim 3.6(6 \mathrm{H}, \mathrm{m}, \mathrm{CON}- \\
\left.\mathrm{CH}_{2} \text { and } \mathrm{N}^{+}-\mathrm{CH}_{2}\right), 3.2\left(6 \mathrm{H}, \mathrm{s}, \mathrm{N}^{+-} \mathrm{CH}_{3}\right), 3.80\left(2 \mathrm{H}, \mathrm{s}, \mathrm{N}^{+-}\right. \\
\left.\mathrm{CH}_{2}-\mathrm{COO}^{-}\right)\end{array}$ & $\begin{array}{l}3300 \\
1635 \\
1540\end{array}$ \\
\hline
\end{tabular}

${ }^{*} 1$ The values in parentheses are calculated for the hydrate containing $3 \mathrm{~mol}$ of water.

*2 The values in parentheses are calculated for the hydrate containing $1 \mathrm{~mol}$ of water.

NMR measurements were carried out under the following conditions : $60 \mathrm{MHz}$; conc., $25 \sim 30 \mathrm{mg} / 0.4 \mathrm{~mL}$; pulse width, 60; pulse interval, $5 \mathrm{~s}$; number of scan; 25; reference, DSS. 
ethanol, isopropyl alcohol and 28\% ammonia aqueous solution applied to the detection of products.

$\left(\mathrm{CH}_{3} \underset{\mathrm{N}}{\mathrm{CH}_{3}} \stackrel{\stackrel{\mathrm{N}}{\mathrm{N}} \mathrm{C}_{3} \mathrm{H}_{6} \mathrm{NHC}\left(\mathrm{CH}_{2}\right)_{2}}{\mathrm{P}_{2}}\right]_{2}+\mathrm{ClCH}_{2} \mathrm{COONa} \longrightarrow$

i a , $n=5$

b, $n=7$
c, $n=9$

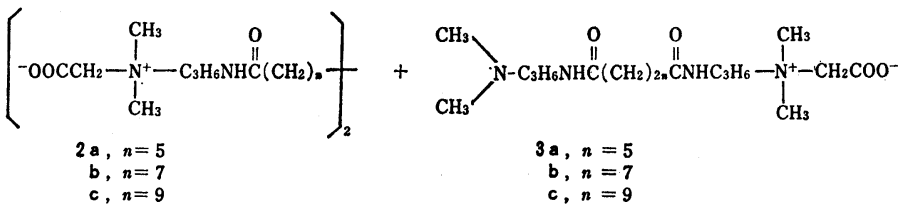

The component which has the $R_{f}$ value of 0.16 was isolated on silica gel column using the similar developing solvents as TLC and this structure was confirmed as $\mathrm{C} 12$ bisamic dobetaine ( 2 a) by elementary analysis, IR and NMR spectral data. The structure of the component having the $R_{f}$ value of 0.40 was confirmed as $\mathrm{C} 12$ monoamidobetaine (3 a) by analysis of the isolated one. Similarly, other monoamidobetaines and bisamidobetaines obtained from the reactions of $\mathrm{C} 16$ or $\mathrm{C} 20$ bisaminoamides and sodium chloroacetate were isolated and these structures were confirmed. Analytical data of C 16 bisamidobetaine (2 b), C 16 monoamidobetaine ( $3 \mathbf{b}$ ), C 20 bisamido= betaine (2 c) and $\mathrm{C} 20$ monoamidobetaine $(\mathbf{3} \mathbf{c})$ as well as $\mathrm{C} 12$ derivatives are shown in Table1.

The reactions of bisaminoamides with so $=$ dium chloroacetate were studied under various conditions. As shown in Table-2, in the case of sodium hydrogencarbonate catalyst the reaction in water or mixed solvent of isopropyl alcohol and water gave bisamidobetaine in good yield. In the case of sodium hydroxide catalyst, the reaction in isopropyl alcohol gave bisamidobetaine in good yield while that in water gave low yield and the recovery of bisamino= amide was diminished. This may be due to the hydrolysis of sodium chloroacetate and bisaminoamide and Hofman degradation of bisamidobetaine by sodium hydroxide.

\subsection{Surface Tension of Aqueous Solu= tion of $a-\omega$-Bisamidobetaine}

Plots of surface tension $(\gamma)$ vs. logarithm of concentration for $\alpha, \omega$-bisamidobetaines are given in Fig.-1. There is no sharp discon= tinuity in the curve for $\mathrm{C} 12$ bisamidobetaine. The sharp discontinuities for $\mathrm{C} 16$ and $\mathrm{C} 20$ bisamidobetaines appeared in their curves. Critical micelle concentrations (cmc) and areas/ molecule at the liquid/air interface were determined from the surface tension vs. log (concentration) plots. The values obtained for

Table-2 Reactions of bisaminoamides with sodium chloroacetate.

\begin{tabular}{|c|c|c|c|c|c|c|}
\hline $\begin{array}{c}\text { Bisamino }= \\
\text { amide } \\
(\mathrm{mmol})\end{array}$ & $\begin{array}{l}\text { Sodium } \\
\text { chloroacetate } \\
(\mathrm{mmol})\end{array}$ & $\begin{array}{l}\text { Catalyst } \\
(\mathrm{mmol})\end{array}$ & $\begin{array}{l}\text { Solvent } \\
(\mathrm{mL})\end{array}$ & $\begin{array}{c}\text { Recovered } \\
\text { bisaminoamide } \\
(\%)\end{array}$ & $\begin{array}{l}\text { Yield of } \\
\text { monobetaine } \\
(\%)\end{array}$ & $\begin{array}{l}\text { Yield of } \\
\text { bisbetaine } \\
\text { (\%) }\end{array}$ \\
\hline $\begin{array}{l}\mathrm{C} 12 \\
(20)\end{array}$ & 50 & $\underset{(4)}{\mathrm{NaHCO}_{3}}$ & $\begin{array}{c}\mathrm{H}_{2} \mathrm{O} \\
(9)\end{array}$ & 3 & 17 & 75 \\
\hline $\begin{array}{l}\mathrm{C} 12 \\
(25)\end{array}$ & 25 & $\underset{(4)}{\mathrm{NaHCO}_{3}}$ & $\begin{array}{c}\mathrm{H}_{2} \mathrm{O} \\
(9)\end{array}$ & 35 & 21 & 35 \\
\hline $\begin{array}{l}\text { C12 } \\
(20)\end{array}$ & 50 & $\underset{(4)}{\mathrm{NaHCO}_{3}}$ & $\begin{array}{c}\mathrm{H}_{2} \mathrm{O} / \mathrm{IPA} \\
(2 / 7)\end{array}$ & 2 & 15 & 77 \\
\hline $\begin{array}{l}\text { C12 } \\
(20)\end{array}$ & 50 & $\underset{(4)}{\mathrm{NaOH}}$ & $\begin{array}{l}\text { IPA } \\
(30)\end{array}$ & 4 & 14 & 67 \\
\hline $\begin{array}{l}\text { C12 } \\
(20)\end{array}$ & 50 & $\underset{(4)}{\mathrm{NaOH}}$ & $\begin{array}{c}\mathrm{H}_{2} \mathrm{O} \\
(9)\end{array}$ & 3 & 20 & 47 \\
\hline $\begin{array}{l}\text { C16 } \\
(10)\end{array}$ & 25 & $\underset{\text { (2) }}{\mathrm{NaHCO}_{3}}$ & $\begin{array}{c}\mathrm{H}_{2} \mathrm{O} / \mathrm{IPA} \\
(12 / 28)\end{array}$ & 3 & 16 & 69 \\
\hline $\begin{array}{l}\text { C16 } \\
(12)\end{array}$ & 30 & $\begin{array}{c}\mathrm{NaHCO}_{3} \\
\text { (2) }\end{array}$ & $\begin{array}{c}\mathrm{H}_{2} \mathrm{O} / \mathrm{IPA} \\
\quad(7 / 23)\end{array}$ & 6 & 17 & 64 \\
\hline $\begin{array}{l}\mathrm{C} 20 \\
(4.4)\end{array}$ & 11 & $\underset{(11)}{\mathrm{NaOH}}$ & $\begin{array}{l}\text { IPA } \\
(10)\end{array}$ & - & 8 & 76 \\
\hline $\begin{array}{r}\mathrm{C} 20 \\
(8.5)\end{array}$ & 30 & $\underset{(2)}{\mathrm{NaHCO}_{3}}$ & $\begin{array}{c}\mathrm{H}_{2} \mathrm{O} / \mathrm{IPA} \\
(12 / 28)\end{array}$ & - & 14 & 68 \\
\hline
\end{tabular}




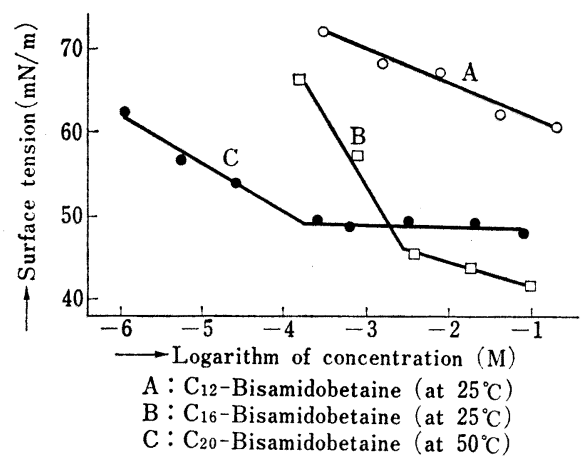

Fig. -1 Plots of surface tension vs. logarithm of concentration for $\alpha, \omega$-bisamido $=$ betaine.

Table-3 Surface active properties of $\alpha, \omega$-bisamidobetaines.

\begin{tabular}{|c|c|c|c|c|}
\hline $\begin{array}{c}\text { Bisamido } \\
\text { betaine }\end{array}$ & $\begin{array}{l}\mathrm{cmc} \\
(\mathrm{M})\end{array}$ & $\begin{array}{c}r_{\mathrm{cmc}} \\
(\mathrm{mN} / \mathrm{m})\end{array}$ & $\begin{array}{c}\text { Surface } \\
\text { excess } \\
\times 10^{10} \\
\left(\mathrm{~mol} / \mathrm{cm}^{2}\right) \\
\end{array}$ & $\begin{array}{l}\text { Area/ } \\
\text { molecule } \\
\quad\left(\AA^{2}\right)\end{array}$ \\
\hline $\mathrm{C} 16$ & $3.5 \times 10^{-3}$ & 45.8 & 3.1 & 54 \\
\hline $\mathrm{C} 20$ & $2.0 \times 10^{-4}$ & 49.3 & 0.87 & 192 \\
\hline
\end{tabular}

cmc and areas/molecule are listed in Table-3. The molecular area of $\mathrm{C} 16$ bisamidobetaine is comparatively large and that of $\mathrm{C} 20$ bis $=$ amidobetaine is very large in contrast with 33 $\AA^{2}$ for sodium dodecyl sulfate ${ }^{12)}$. This fact may rise from the loosely packed micelle of C 20 bisamidobetaine because of the presence of the two polar groups having the large sectional area in the molecule.

\subsection{Catalytic Activity for the Halide Displacement Reaction}

Halide displacement is one of the most important reaction for the synthesis of alkyl iodides and fluorides. Catalytic activity of $\alpha, \omega$ bisamidobetaines for this reaction was studied. As shown in Table-4, the catalytic activity of $\alpha, \omega$-bisamidobetaine was increased with increaseing chain length. The activity of $\mathrm{C} 20$ bisamidobetaine was superior to that of tetra= ethylammonium bromide (TEAB), although it was slightly lower than that of tetrabutylam= monium bromide (TBAB), C 10 monoamido= betaine and commercial monoamidobetaine.

\subsection{Lime Soap Dispersing Ability}

The lime soap dispersant requirements (LSDR) of $\alpha, \omega$-bisamidobetaines are shown in Table-5. LSDR of C 20 bisamidobetaine
Table-4 Halide displacement reactions in the presence of bisamidobetaines. $\mathrm{C}_{8} \mathrm{H}_{17} \mathrm{Br}+\mathrm{MI} \rightarrow \mathrm{C}_{8} \mathrm{H}_{17} \mathrm{I}+\mathrm{MBr}$

\begin{tabular}{|c|c|c|}
\hline Reagent & Catalyst & $\begin{array}{l}\mathrm{C}_{8} \mathrm{H}_{17} \mathrm{I} \\
(\%)\end{array}$ \\
\hline $\mathrm{NaI}$ & C 12-Bisamidobetaine (2 a) & 4 \\
\hline $\mathrm{NaI}$ & C 16-Bisamidobetaine (2 b) & 48 \\
\hline $\mathrm{NaI}$ & C 20-Bisamidobetaine (2 c) & 82 \\
\hline $\mathrm{KI}$ & C 16-Bisamidobetaine (2 b) & 61 \\
\hline $\mathrm{KI}$ & C 20 -Bisamidobetaine (2 c) & 79 \\
\hline $\mathrm{NaI}$ & TEAB* & 5 \\
\hline $\mathrm{NaI}$ & TBAB** & 95 \\
\hline $\mathrm{NaI}$ & C 10-Monoamidobetaine*** & 92 \\
\hline $\mathrm{NaI}$ & Commercial C 12 monobetaine & 93 \\
\hline $\mathrm{NaI}$ & $\begin{array}{l}\text { Commercial C } 12 \text { monoamido= } \\
\text { betaine }\end{array}$ & 92 \\
\hline
\end{tabular}

* Tetraethylammonium bromide

** Tetrabutylammonium bromide

*** $\mathrm{C}_{9} \mathrm{H}_{19} \mathrm{CONHC}_{3} \mathrm{H}_{6} \mathrm{~N}^{+}\left(\mathrm{CH}_{3}\right)_{2} \mathrm{CH}_{2} \mathrm{COO}^{-}$

Table-5 Lime soap dispersing power of $\alpha, \omega$-bisamidobetaines.

\begin{tabular}{l|c}
\hline \multicolumn{1}{c|}{ Amidobetaine } & LSDR* \\
\hline C 12-Bisamidobetaine (2 a) & $200<$ \\
C 16-Bisamidobetaine (2 b) & 8.5 \\
C 20-Bisamidobetaine (2 c) & 2.5 \\
C 10-Monoamidobetaine** & 35 \\
Commercial C 12 monobetaine & 20 \\
Commercial C 12 monoamidobetaine & 7 \\
\hline
\end{tabular}

* Minimum number of surfactant required to prevent precipitation of $100 \mathrm{~g}$ sodium oleate in hard water (300 ppm)

** $\mathrm{C}_{9} \mathrm{H}_{19} \mathrm{CONHC}_{3} \mathrm{H}_{6} \mathrm{~N}^{+}\left(\mathrm{CH}_{3}\right)_{2} \mathrm{CH}_{2} \mathrm{COO}^{-}$

is 2.5 , which is one of the most excellent values among those available from the literature, and is much better than that of $\mathrm{C} 10$ mono= amidobetaine having the same hydrophilicity. This may be explained by the large molecular area of C 20 bisamidobetaine. LSDR of C 16 bisamidobetaine was comparable to that of sodium $\alpha$-sulfomethyltallowate ${ }^{13)}$, which is known as a readily available lime soap diso persing agent.

\section{Conclusion}

New type of $\alpha, \omega$-amphoteric surfactants containing bisamidobetaine groups in both sides of the molecule were synthesized from long-chain dibasic acids in good yield. In 
comparison of $\alpha, \omega$-bisamidobetaines with monoamidobetaines containing same proportions of the hydrophilic group, the catalytic activity for the halide displacement reaction of both types of amidobetaines was comparable. The lime soap dispersing ability of the former was superior to that of the latter. The excellent lime soap dispersing ability of $\alpha, \omega$-bisami $=$ dobetaines may be attributed to bulkiness of the two polar amphoteric groups.

(Received Feb. 9, 1987)

\section{References}

1) R. Ernst and E.J. Miller, Jr., "Amphoteric Surfactants", Ed. by B.R. Bluestein, and C.L. Hilton, Marcel Dekker Inc., New York (1982), p. 71 .

2) Y. Gama, and H. Suzuki, J. Jpn. Oil Chem. Soc. (YUKAGAKU), 32, 480 (1983).

3) I. Danielson, Acta Acad. Abo. Ser., B 20, 7 (1956)

4) P.H. Elworthy, J. Pharm. Pharmacol., 11, 557 (1959).

5) M. Ueno, T. Hikota, T. Miyata, and K. Mes gro, J. Am. Oil Chem. Soc., 49, 250 (1972).

6) M. Ueno, S. Yamamoto, and K. Megro, $J$. Am. Oil Chem. Soc., 51, 373 (1974).

7) M.J. Rosen, M. Baum, and F. Kasher, J. Am. Oil Chem. Soc., 53, 742 (1976).

8) H. Takahashi, T. Fujiwara, and T. Kuwamu= ra, J. Jpn. Oil Chem. Soc. (YUKAGAKU), 24, 36 (1975).
9) T. Takeda, S. Yamamura, F. Takeda, and M. Nakamura, Kagaku To Kogyo (Osaka), 59, 313 (1985).

10) T. Takeda, S. Yamamura, S. Ogawa, K. Hon= da, and M. Nakamura, Chem. Express, 1, 307 (1986).

11) H.C. Borghetty, and C.A. Bergman, J. Am . Oil Chem. Soc., 27, 88 (1950).

12) G. Nilsson, J. Phys. Chem., 61, 1135 (1957).

13) B.L. Kapur, J.M. Solomon, and B.R. Blue= stein, J. Am. Oil Chem. Soc., 55, 549 (1978).

長鎖二塩基酸からの $\alpha, \omega$-ビス アミドベタイン型両性界面活性 剤の合成と性質

山村伸吾・小川晋一・本田圭介 中村正樹 ·武田徳司

大阪市立工業研究所（甬536 大阪市域東区森の宮 1-6-50)

2 個のベタイン基をもつ $\alpha, \omega$-型両性界面活性剂が, アルカン二酸と $N, N$-ジメチル-1,3-プロパンジアミン との反応とそれに続くクロロ酢酸ナトリウムでの第四級 化反応によって合成された。第四級化反忘は，炭酸水素 ナトリウムあるいは水酸化ナトリウムを触媒として用い 水中あるいはイソプロピルアルコールと水の混合溶媒中 で行った。

$\alpha ， \omega$-ビスアミドベタイン水溶液の性質について検討 した。ヘキサデカン二酸及びイコサン二酸から合成した $\alpha, \omega$-ビスアミドベタインは，八ライド置換反応に対し て良好な触媒活性を示し, また優れたカルシウムセッケ ン分散能を示した。 